\title{
Innovations that changed mammalogy: field techniques for karyotyping
}

\author{
Hugh H. Genoways, Robert M. Timm, * and Suzanne B. McLaren \\ University of Nebraska State Museum, University of Nebraska-Lincoln, Lincoln, NE 68588, USA (HHG) \\ Department of Ecology \& Evolutionary Biology and Biodiversity Institute, University of Kansas, Lawrence, KS 66045, \\ USA (RMT) \\ Section of Mammals, Edward O'Neil Research Center, Carnegie Museum of Natural History, Pittsburgh, PA 15206, USA (SBM) \\ *Correspondent: btimm@ku.edu
}

Our fourth selection for an innovation that changed mammalogy is actually a series of innovations that accumulated over a period of at least 15 years, and opened the way for researchers to be able to karyotype wild mammals under the most challenging fieldwork conditions. By 1950, the basics of chromosomes were understood, but getting accurate chromosome counts was "exceedingly tedious and often inaccurate" (Baker and Hafner 1994:313). The problem for mammals was made more difficult by the high chromosome counts that characterize many species. For example, the human chromosome count was believed to be 48 at this time, rather than the 46 we know today. The old technique was to squash cells on a microscope slide with a coverslip, resulting in poorly spread chromosomes with overlapping sections that did not focus in the same plane under a microscope. The chances of viewing a good (countable) spread were diminished further by the fact that, under normal conditions, there is a limited number of cells in metaphase at any one time (Matthey 1953; Sachs 1953; Hsu 1979).

The first innovation initially came through a laboratory error, but was quickly recognized and incorporated into routine procedures. This involved treatment with a hypotonic saline solution that swelled the cells and disturbed the spindles of the dividing cells, thus allowing the metaphase chromosomes to be spread apart on the microscope slide and available for study and counting (Hsu 1952, 1979; Hughes 1952; Makino and Nishimura 1952; Hsu and Pomerat 1953). Much of the early karyotypic work was done in vitro with tissue cultures (Tjio and Levan 1956), but Ford and Hamerton (1956) using an in vivo method securing the tissue from the bone marrow of freshly sacrificed animals. They also used a colchicine (more recently Velban/vinblastine sulfate) pretreatment, injecting the animals $1 \mathrm{~h}$ prior to sacrifice. The pretreatment with a mitotic inhibitor stopped cell division at the metaphase plate, greatly increasing the number of spreads in which the chromosomes could be counted.

In addition to attempting to spread the chromosomes by squashing with the coverslip in the old technique, air drying (Tjio and Whang 1962) and freezing (Carr and Walker 1961) had been used. Another methodological breakthrough was the blaze-dry method of Scherz (1962), which "spread the chromosomes effectively from a single cell into a broader field for easier viewing of chromosomal details" (Baker and Hafner 1994:313). It could be quite exciting and nerve-racking at the same time to light the fixative containing methanol and your sample on fire after several hours of preparation.

By the early 1960s, researchers were publishing images of the karyotypes of mammals and undertaking comparative studies that had systematic and evolutionary implications (Tamsitt 1960; Chu and Bender 1961; Shaver 1962; Hsu et al. 1963). Particularly active during this time was Charles F. Nadler at the Northwestern University Medical School who was focusing his research on the relationships of North American ground squirrels and chipmunks in collaboration with Robert S. Hoffmann at the University of Kansas and others (Nadler 1962, 1966; Nadler and Block 1962; Nadler and Hughes 1966). The Journal of Mammalogy began publishing chromosomal studies in 1966 with articles by Nadler, Nadler and Hughes, and Singh and McMillan (1966) with all showing karyotypes, and Nadler (1966) presenting a diagram of hypothetical chromosomal changes in ground squirrels (for more details about this time period, see Bradley and Dowler 2019).

Methodological innovations in cytogenetics in the years 1966-1967 "triggered a major thrust in this type of research worldwide. Instrumental in development of these new methods was James L. Patton, then a graduate student at the University of Arizona" (Baker and Hafner 1994:315). Patton (2005) explained that in the summer of 1965 he attended a 2-week course

(C) The Author(s) 2020. Published by Oxford University Press on behalf of the American Society of Mammalogists, www.mammalogy.org. 
in cytogenetic methods at Brown University. He was the only graduate student among the 20 attendees, having gained admission based on the academic propinquity of his graduate advisor, Bill Heed, and the organizers of the course. During this course, he met Dr. T. C. Hsu, already a world leader in comparative mammalian genetics, showing him photomicrographs of some Perognathus karyotypes from his thesis. According to Dr. Hsu (1979:69): "They were not impressive. I offered to help him in cytology if he would help me in mammalogy, including procurement of specimens. It turned out I got the better end of the bargain." Patton's (2005:266) assessment was that Dr. Hsu "offered on the spot to bring me to his lab in Houston for training. I went there for two weeks that fall, he visited Tucson in February 1966" and accompanied a group of graduate students to the field in the Patagonia Mountains. The association of Patton and Hsu led to a lineage of mammalogists with interests and training in cytogenetics, many of whom spent time in Hsu's laboratory at M. D. Anderson Hospital in Houston. Among the people in this lineage were Robert J. Baker, Frederick F. B. Elder, Alfred L. Gardner, Amara Markvong, James T. Mascarello, and A. Dean Stock. The major contributions of Patton (1967) and Baker (1970) to the field of mammalian cytogenetics, in developing convenient techniques for use under field conditions, are still widely cited in the literature today (for later updates, see Baker and Qumsiyeh 1988; Baker et al. 2003). As Baker (1970:66) stated, the "technique for somatic chromosomes is relatively simple, requiring a minimum of equipment. With the use of a hand centrifuge it can be adapted to field situations."

We have chosen to emphasize the innovation of field karyotyping here because prior to its availability, mammalogists had "few easily quantified characters that provided systematic resolution among closely related species" (Baker and Hafner 1994:310). Previously, all systematic research was based on morphological characteristics, but the karyotype represented the first step into molecular biology for mammalogy. Because these techniques were adaptable to field conditions and were affordable, the full range of the diversity of the class Mammalia became accessible to mammalogists with interests in molecular biology. The study of karyotypes further proved to be the gateway to a wide range of studies in molecular genetics, including $\mathrm{C}, \mathrm{G}, \mathrm{Q}, \mathrm{R}$ banding, mitochondrial DNA, ribosomal DNA, nuclear DNA, satellite DNA, cytochrome- $b$, fluorescence in situ hybridization, microsatellites, whole chromosome paints, heterochromatin, nucleolus organizer regions (NORs), and genomics. In fact, the graduate students and young scientists who led the push into cytogenetics put mammalogy at the forefront of this revolution in molecular genetics. However, their primary skills were a deep knowledge of wild mammals under field conditions, along with strong laboratory programs. Obviously, the field of karyology had a huge impact on systematics. Further, karyology innovations contributed to the debates surrounding deme-size models, rates of evolution, $c$-value paradox, DNA content, genome organization, and related studies.

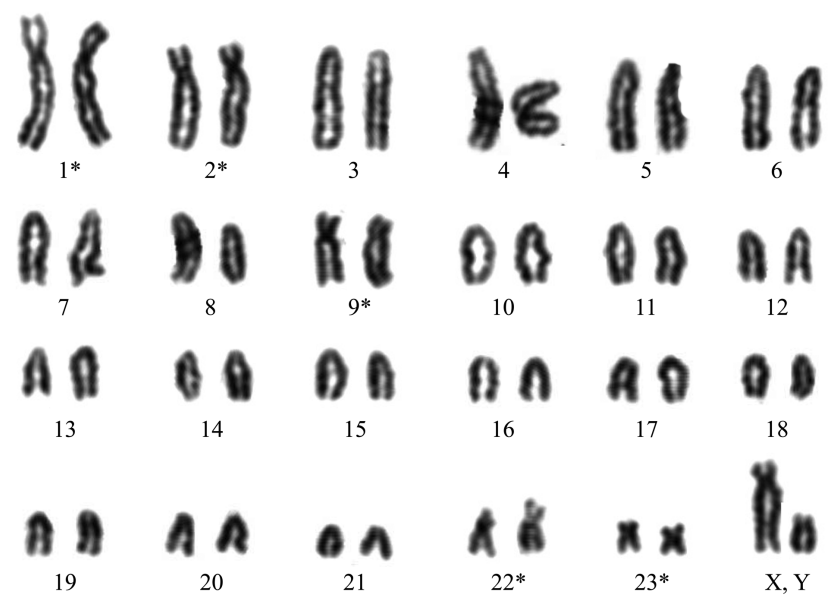

Fig. 1.-Karyotype of the holotype of Peromyscus kilpatricki from Zitácuaro, Michoacán (Texas Tech 104808), as described by Bradley et al. (2017). Chromosome presentation and numbering follows that presented in Committee for Standardization of Chromosomes of Peromyscus (1977). An asterisk (*) indicates chromosomes that are biarmed. For this individual $2 \mathrm{~N}=48$ and $\mathrm{FN}=56$. Courtesy of Robert D. Bradley, Vicki J. Swier, and Cody W. Thompson.

\section{ACKNOWLEDGMENTS}

Our special thank you for previewing this manuscript to our colleagues Robert D. Bradley, Meredith J. Hamilton, Ed Heske, James L. Patton, and Luis A. Ruedas. We appreciate Robert Bradley making the karyotype of Peromyscus available for Fig. 1.

\section{Literature Cited}

BAKer, R. J. 1970. Karyotype trends in bats. Pp. 65-96 in Biology of bats (W. A. Wimsatt, ed.). Academic Press. New York.

Baker, R. J., AND M. S. HAfner. 1994. Cytogenetics. Pp. 310-322 in Seventy-five years of mammalogy (1919-1994) (E. C. Birney and J. R. Choate, eds.). Special Publication, American Society of Mammalogists. Lawrence, Kansas.

Baker, R. J., M. Hamilton, AND D. A. PArish. 2003. Preparations of mammalian karyotypes under field conditions. Occasional Papers, Museum of Texas Tech University 228:i + 1-8.

BaKer, R. J., And M. B. QumsiYeh. 1988. Methods in chiropteran mitotic chromosomal studies. Pp. 425-435 in Ecological and behavioral methods, for the study of bats (T. H. Kunz, ed.). Smithsonian Institution Press. Washington, D.C.

Bradley, R. D., and R. C. Dowler. 2019. A century of mammal research: changes in research paradigms and emphases. Journal of Mammalogy 100:719-732.

Bradley, R. D., N. Ordóñez-Garza, G. Ceballos, D. S. Rogers, AND D. J. Schmidly. 2017. A new species in the Peromyscus boylii species group (Cricetidae: Neotominae) from Michoacán, México. Journal of Mammalogy 98:154-165.

Carr, D. H., AND J. E. Walker. 1961. Carbol fuchsin as a stain for human chromosomes. Stain Technology 36:233-236.

Chu, E. H., And M. A. Bender. 1961. Chromosome cytology and evolution in primates. Science 133:1399-1405.

Committee For Standardization of Chromosomes of Peromyscus. 1977. Standardized karyotype of deer mice, Peromyscus (Rodentia). Cytogenetics and Cell Genetics 19:38-43. 
Ford, C. E., And J. L. Hamerton. 1956. A colchicine, hypotonic citrate, squash sequence for mammalian chromosomes. Stain Technology 31:247-251.

Hsu, T. C. 1952. Mammalian chromosomes in vitro. 1. The karyotype of man. Journal of Heredity 43:167-172.

Hsu, T. C. 1979. Human and mammalian cytogenetics: an historical perspective. Springer-Verlag. New York.

Hsu, T. C., AND C. M. Pomerat. 1953. Mammalian chromosomes in vitro. II. A method for spreading the chromosome cells in tissue culture. Journal of Heredity 44:23-29.

Hsu, T. C., H. H. Rearden, and G. F. Luqurette. 1963. Karyological studies of nine species of Felidae. American Naturalist 97:225-234.

Hughes, A. 1952. Some effects of abnormal toxicity on dividing cells in chick tissue culture. Quarterly Journal of Microscopical Science 93:207-220.

Makino, S., AND I. Nishimura. 1952. Water-pretreatment squash technic; a new and simple practical method for the chromosome study of animals. Stain Technology 27:1-7.

Matthey, R. 1953. Les chromosomes des Muridae. Revue Suisse de Zoologie 60:225-283.

NADLER, C. F. 1962. Chromosome studies in certain subgenera of Spermophilus. Proceedings of the Society for Experimental Biology and Medicine 110:785-788.

Nadler, C. F. 1966. Chromosomes and systematics of American ground squirrels of the subgenus Spermophilus. Journal of Mammalogy 47:579-596.

Nadler, C. F., AND M. H. Block. 1962. The chromosomes of some North American chipmunks (Sciuridae) belonging to the genera Tamias and Eutamias. Chromosoma 13:1-15.
Nadler, C. F., And C. E. Hughes. 1966. Chromosomes and taxonomy of the ground squirrel subgenus Ictidomys. Journal of Mammalogy 47:46-53.

Patton, J. L. 1967. Chromosome studies of certain pocket mice, genus Perognathus (Rodentia: heteromyidae). Journal of Mammalogy 48:27-37.

Patton, J. L. 2005. Species and speciation: changes in a paradigm through the career of a rat trapper. Pp. 263-276 in Going afield (C. J. Phillips and C. Jones, eds.). Museum of Texas Tech University. Lubbock, vi $+289 \mathrm{pp}$.

SACHS, L. 1953. Simple methods for mammalian chromosomes. Stain Technology 28:169-172.

Scherz, R. G. 1962. Blaze drying, by igniting the fixative, for improved spreads of chromosomes in leucocytes. Stain Technology 37:386.

Shaver, E. L. 1962. The chromosomes of the opossum, Didelphis virginiana. Canadian Journal of Genetics and Cytology 4:62-68.

Singh, R. P., And D. B. McMillan. 1966. Karyotypes of three subspecies of Peromyscus. Journal of Mammalogy 47:261-266.

Tamsitt, J. R. 1960. The chromosomes of the Peromyscus truei group of white-footed mice. Texas Journal of Science 12:152-157.

TuIo, J. H., And A. Levan. 1956. The chromosome number of man. Hereditas 42:1-6.

TuIo, J. H., AND J. Whang. 1962. Chromosome preparations of bone marrow cells without prior in vitro culture or in vivo colchicine administration. Stain Technology 37:17-20.

Submitted 29 May 2020. Accepted 24 July 2020.

Associate Editor was Luis A. Ruedas. 